\title{
THRESHOLDS IN THE SETTINGS OF MEDIEVAL MONUMENTS: THE CASE OF THE PORTUGUESE ROMANESQUE ROUTE
}

\author{
M. MALHEIRO \\ Universidade Lusíada Norte-Porto, Portugal CITAD - Investigation Center in Territory, Architecture and Design
}

\begin{abstract}
The importance of the setting and the immediate surroundings of an architectural heritage site has become an increasingly valued concept; the need for its protection was the focus of a recent international charter. The progressive and predominant role of the setting is to establish the relationship between the architectural heritage site and local people and to integrate the monument into their lives. This paper presents examples of the changes and maintenance carried out to monument settings, in particular, where the thresholds of the settings are being considered as an extended concept of 'place'. Based on a study of monuments on the Portuguese Romanesque Route, comprising chapels, churches and monasteries, the purpose of this paper is to reflect on the importance of the monuments' boundary settings, their evolution and permanence in the territory, and the significance of the monuments, especially for the people who live with them. This reflection also aims to draw attention to the need for considering this viewpoint in future interventions in the settings of medieval heritage sites.

Keywords: architectural heritage settings, Portuguese Romanesque Route, protection zones, regional and urban planning, threshold spaces.
\end{abstract}

\section{INTRODUCTION}

The settings of monuments are elements that have received special attention because of their constituent aspects and their capacity to greatly enhance the monument: these are most significant for the protection of the architectural heritage and for the tangible or intangible elements that compose the place in which the settings belong. The purpose of this article is to present the conclusions from the recent study of the enhancement and protection of the settings of monuments of the Route of the Romanesque [1], in 2015, which focused on territorial issues. It covers the settings of 29 monuments spread along the northern region of Portugal, including two chapels, 21 churches and six monasteries. The inflexible way in which Portuguese legislation has dealt with these issues has led the Romanesque Route to define an instrument that is able to record the changes occurring in the settings and the possibility or need for intervention. This analysis allowed us to understand the tangible and intangible connections between the architectural heritage and its cultural, physical, visual and immaterial settings. The perception of the relationship between monument and place, and the proposal of suggested interventions, highlighted the need to establish criteria for intervention where the border areas or thresholds have proved extremely important in the settings of the architectural heritage. Although the study focuses on different aspects and suggestions for the characterization and protection of the settings, this article concentrates on the threshold of those spaces that make up the setting of the architectural heritage site, given their relevance to the context, integrity and enhancement of the significance of the monuments. 


\section{ARCHITECTURAL HERITAGE'S SETTING}

\subsection{The Portuguese legislation}

The process of defining the right setting for a particular architectural heritage site is a difficult task, being poorly defined in national legislation or heritage charters, especially in terms of the criteria to be taken into account. In this sense, the inventory is a very important element in defining a strategy for the protection and enhancement of heritage [2]. The analysis carried out of the two inventories of the Portuguese tutelage organization, the General Directorate for Cultural Heritage (DGPC), one made by the extinct IPPAR [3] and other made by the extinct DGEMN [4], indicates that it is critical to characterize these settings, or at least it should be. However, it appears that the settings are not taken into account in both existing inventories in the DGPC, which merely relate to the characterization of the monument.

Regarding the instruments to ensure the protection of the architectural heritage setting, these are available through the definition of protected areas. The Portuguese Law of Cultural Heritage [5] states that the protection of the settings of the classified buildings, complexes and sites, or of those being classified, is carried out through the delimitation of protected zones that, in legal terms, 'are administrative rights they attach to the tutelage control of the interventions to be carried out within its boundaries' [6]. In this sense, the central administration pronounces in mandatory terms on interventions that propose any changes in ' $(. .$. topography, alignments, building heights, and in general, the distribution of volumes and buildings' roofs or the exterior claddings of buildings' [7], which are proposed within the protection zones. Thus, they often fail to set the criteria and 'supplements' for interventions in the settings of architectural heritage sites, especially the surrounding areas of heritage assets; for example, changes in the limits of these spaces and materials, and the colours and textures of which they are composed, are crucial for the contextualization of the settings, as shall be discussed.

Portuguese legislation provides for the existence of two types of protected areas: a general protection zone (ZP) and a special protection zone (ZEP). It can also include, as an alternative, a provisional special protection zone (ZEPP), with limits adapted to the characteristics of the asset and implantation site of the monument. The procedure for setting up a ZEP should be via case study and 'technically determined, depending on a dividing line that results from a study of the assembly and nexus that exists between the classified monument and its setting' [8]. These zones consist mainly of 'standard areas that define pieces of land in the territory, always cut with the same mould and where there is no effective and proven relation between the immoveable heritage and its setting, beyond mere physical proximity' [9]. The demarcation is performed in an abstract way around the architectural element, although, studied case by case, where the limits are defined only on the basis of unilateral relationship and not of interdependence, that is, in the object's domain relation to the landscape. Reordering or new intervention is also not countenanced, only preserving areas or keeping them as they are, not allowing changes, whether they are in urban or rural areas. Occasionally it means setting up non aedificandi areas where any construction is forbidden, in order to create buffer zones. It is a defensive protection that considers that the setting is in harmony with the heritage assets, where its characteristics remain unchanged. This condition is not compatible with the areas where most of the monuments of the Romanesque Route are located, because their predominant insertion in peri-urban areas is subject to profound character changes. In addition to the weakness of the Portuguese legal instruments and the transformation of the territory in which they are located, it is found that, of the 29 monuments analysed, only seven have a defined 
ZEP and eight have a ZP, due to their classification as national monuments. The remaining 14 monuments have no protection zone, confirming the necessity and urgency for the study to be carried out.

\subsection{Heritage charters}

The importance of the setting has taken a leading role in the protection of architectural heritage, significantly referred to in the various heritage charters since the Venice Charter (1964). The Xi'an Declaration (2005) emphasizes the need to recognize settings for the significance and character of the heritage structure and consequently the need to develop tools that promote their conservation and management. This focused attention on the setting due to the changes occurring in cities, landscapes and heritage routes: changes in lifestyles, agriculture, development and tourism. It defines the setting of a heritage structure as an immediate and extended environment that is part of, or contributes to, its significance and distinctive character' [10], which should consider interactions between physical and visual aspects with the natural environment, social and spiritual, giving it an intangible character. To protect this setting, the declaration recommends the definition of a protection or buffer zone around heritage structures that reflects and conserves the significance and distinctive character of their setting [10]. More recently, we have seen the Quebec Declaration (2008) on the preservation of the spirit of the place, being defined as 'the tangible (sites, buildings, landscapes, routes, objects) as well as intangible elements (memories, narratives, written documents, festivals, commemorations, rituals, traditional knowledge, values, textures, colours, odours), which all significantly contribute for place making and providing its spirit' [11]. It also considers that the transmission of the spirit of the place occurs essentially through people, especially local communities which live within heritage places.

These two declarations express the importance of the place and setting in which heritage architecture is located, highlighting the need for the involvement of people, in particular those who daily interact with it. They stress the need to care for the maintenance or re-creation of links between communities and their cultural heritage. Communities should experience their monuments, not only aesthetically or at the level of contemplation but simultaneously via the establishment of material and emotional connections, creating new or replacing old dialogues with their monuments. In determining these relationships, the place and setting play a predominant role, with the need to develop instruments that promote their conservation, management and development.

\section{THE DELIMITATION OF THE SETTING}

It has been demonstrated that there has been a substantial transformation of the heritage concept, extending its limits from a singular and isolated element to a broader set of heritage assets situated within their environment (physical and social). However, this extension of boundaries creates difficulties in the delimitation, definition and characterization of the interventions to be undertaken.

The establishment of a physical and symbolic space, to which the heritage asset relates, and in which it is integrated and participates, is as important as knowing how to act on it, in order to preserve its values and its relationship with the heritage asset and thus safeguard its character and significance. On the other hand, besides these actions, it is important to emphasize the significance of the architectural heritage, and the social, cultural, economic and educational totality should be considered, defining the formation and development of the individuals, in its relationship with the environment, which could not be achieved in a protected level, via the presence of the setting. 
J.C. Ruiz says that the most effective means to define and preserve lie in territorial and urban planning legislation. These instruments should not prevent the changes that the properties are subject to, in a territory also subject to constant and profound changes, because of depopulation, abandonment and metamorphosis of the agricultural landscape, but should bring awareness of the weighting and regulation thereof, in order to minimize their impact on reading and interpreting the meaning of the heritage asset. The design of the setting is not seen as a space surrounding the heritage buildings, similarly valued, but as a set of spaces linked to architectural heritage, whose interventions demand a need for action. Thus, the setting 'is a cause or an agent, already present or possible, of deterioration values of the heritage asset, so it makes no sense to identify these agents without defining measures to prevent or solve the damage they can cause' [12]; that is, it only makes sense to delimitate the setting along with the presentation of proposals for intervention or for their maintenance.

Any methodology intending to establish general criteria for the delimitation or action to be undertaken in the setting should pay special attention to perceptual relations or to the monument perceptual requirements. Thus, J. C. Ruiz argues that the delimitation of the setting should enhance values that are 'significant for the heritage assets, so that their assessment allows extracting and enhancing their meanings' [12]. Thus, in this sense, the threshold between the monument and the settings has supreme dominance.

Subjective factors and references are taken into account in the significance of the monument, besides their objective nature, i.e. its existence or physical characteristics. According to J. C. Ruiz, the significant perceptual relation between the monument and its setting can be characterized by three factors or dimensions: 'The identification of the architectural heritage and the settings as place; The integration of the architectural heritage in the landscape; The existence and utilization of historical and/or collectively consolidated aesthetic perspectives' [12]. This significant capacity is revealed in the setting through space symbols and physical references relating to place, maintaining and strengthening the identity of a community. Its cultural dimension is the collective memory of the community with which it coexists. The definition and characterization of a setting as a 'place', and any intervention from this perspective, are appropriate criteria to ensure the ends pursued in relation to the enhancement of the meanings of monuments, taking into account that these are organizing the space around them and are centres with significance. Thus, it is possible to treat the setting as a public space defined by a variety of elements and functions, variables in time (phenomenological life cycles), with a diversified use, which subsequently leads to a claim and vitalization of the significance of the monument, given the physical and functional link conditions existing between the setting and the heritage asset.

The setting is a spatial unit, which acquires a distinctly significant character, deduced by human experiments of it, involving emotional reactions. It is a living space, but as a spatial unit it does not have scale. It is identified by the strength of the link established with the monument. It is not a unitary space but, rather, the result of spaces that require interventions, linked to the monument and with imprecise limits [12]. Thus, any use attributed to this public space or to its design should always demonstrate a link to the monument, as well as enhance the enjoyment of public spaces that comprise it. It is through the concept of landscape that the actions to implement the interventions are substantiated. For the conformation of place, formed by the setting and architectural heritage of which it is part, it is necessary to understand it as a specific space defined by a set of shapes, textures, colours, meanings and uses. The landscape and the concept of landscape have a large formal character, which implies a perceptive recognition of it. It also has the capacity to place the identity of a territory in a given context and a unitary condition. It is also crucial to maintain this view of the setting as a place to enhance the historical perspective by its landscape. 

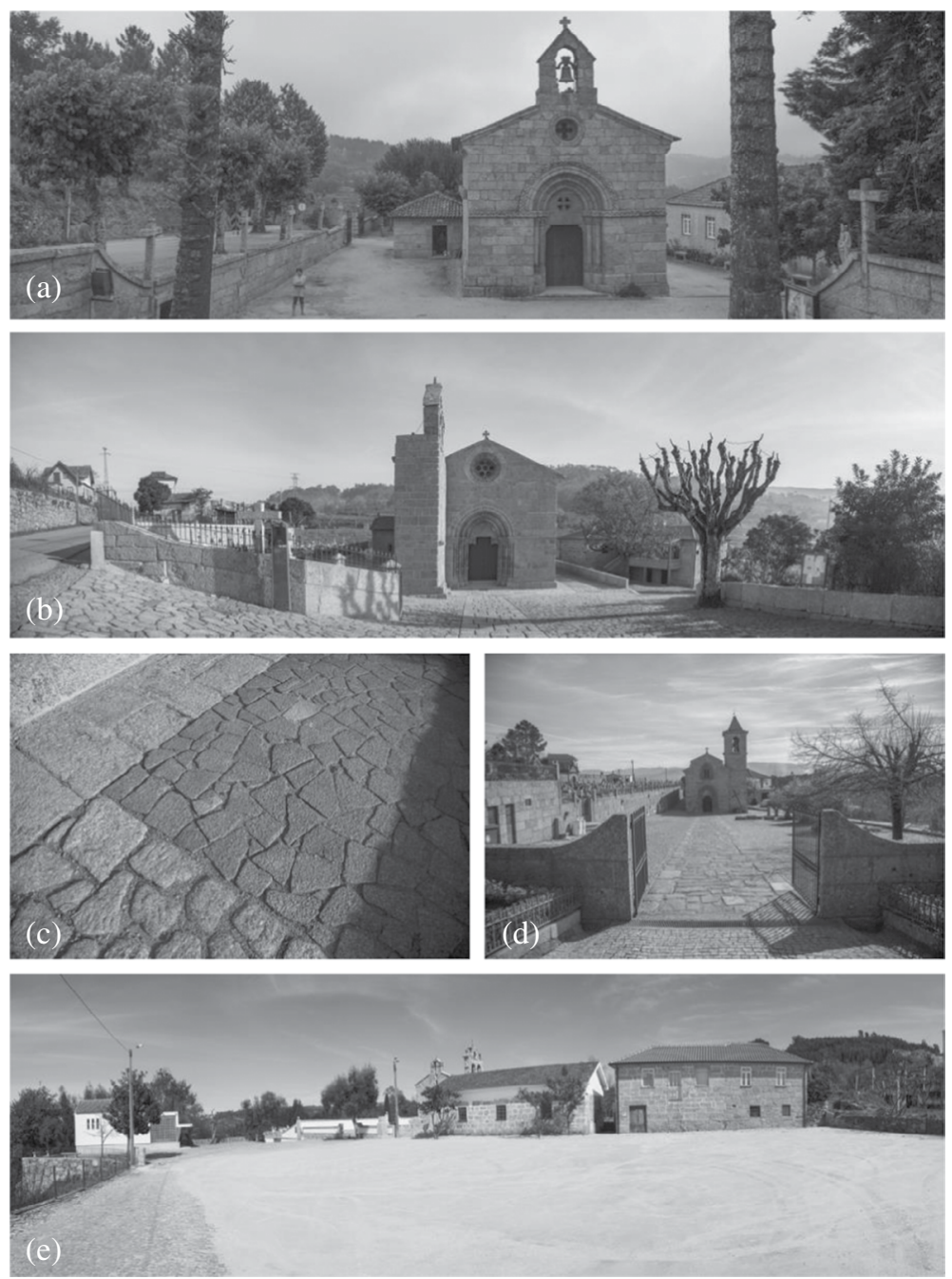

Figure 1: (a) Photographs of the Santo Isidoro Church. (b) Tabuado Church. (c) Granite cobblestones that make up the churchyard pavement of Tabuado Church. (d) Vila Boa de Quires Church. (e) The surroundings of Jazente Church.

Thus, it is verified that the setting is a public space, and it is important that people experience it and relate to the monument. Basically, it is necessary to create a relationship, even if not in an obvious way, for people to contribute to the maintenance of the physical and spiritual significance of the monument. However, people should be encouraged to experience the settings as something more than the site or background of the architectural heritage.

In this way of dealing with the settings as 'place', looking at them as if integrating into the landscape, one must pay attention to the boundaries as the most basic community component [13], as mentioned by J. B. Jackson. The monument was installed in a given place, it organized its surrounding areas and its limits are therefore unequivocal, permanent, inviolable and essential. In this regard, the setting is a composition of spaces, and it is also a composition or net of boundaries. The medieval church always had a fence or wall to delimit a space that was 
enclosed and excluded, working as a surrounding buffer zone of empty space to yield them dignity and grandeur. During the Portuguese Middle Ages, on a macro scale, we also had an administrative organization of the territory divided into 'lands': agricultural plots of land with well-defined borders. This structuring of the territory formed a 'balancing agro system between cattle farming and the production of cereals and some horticultural products', forcing 'the construction of fences: ditches, hedges and walls, made up, not so much to divide property but to maximise the breeding of pigs, cattle and other domestic animals' [14]. Boundaries are essentially created by good neighbourliness. These 'rural communities are organized around a church, ecclesia, with its ground burial space that helps them to build the social neighbourhood, and ensures them of God's and the saints' protection for the living and the dead' [14].

The church is 'the best symbol to show that a territory is owned and organized' by structuring spaces, edifices and boundaries that defined an arrangement for stabilizing social relations. These limits gave a permanent human quality to what would otherwise be an amorphous stretch of land. In this specific case, it turns out that it is extremely important to define the setting, while increasing the importance of the heritage asset, because it represents a social order where community identity is revealed, part of an ethnic or religious society. So it is important to understand these spaces in historical terms. Every traditional public space, whether religious, political or ethnic, 'displays a variety of symbols, inscriptions, pictures, monuments, not as works of art but to remind people of their civic privileges and duties' and 'tacitly to exclude the outsider' [13]. Settings not only enhance the significance of the monument but also create a 'civic awareness' for their protection.

Therefore, it is considered significant to remember these boundaries, as Jackson describes them, not as a skin but as a packaging or envelope, a form of visibility, a corporeal identity of the monument that it involves. The setting should be defined in terms of its boundaries, thresholds, and its visible features.

\section{MONUMENT SETTINGS OF THE ROMANESQUE ROUTE}

The study of the conservation and enhancement of monument settings of the Romanesque Route was carried out by a multidisciplinary team comprising the disciplines of history, archaeology, civil engineering, electrical engineering, landscape architecture and architecture, which coordinated the work. The study, commissioned by the Romanesque Route, analysed the settings of the monuments that constitute the route, encompassing churches, chapels, monasteries, bridges, castles and memorials. The main objective was to define intervention strategies and engage management in line with the municipalities involved and the DGPC. In this article are analysed eight monuments, consisting of churches, chapels and monasteries, represented in Fig. 3, showing the paradigmatic examples that serve as case studies to demonstrate the relevance of interdependent spaces to heritage assets and the function of the thresholds of these spaces, in the context of the setting.

One aspect that should be taken into account in the definition of the setting and how to intervene is the type of monument that it supports. The latter is associated with known historic interdependent spaces, such as burial grounds, yards, various barns and fences. Thus, the interpretation of the settings of the buildings is organized according to their typologies.

\subsection{Churches}

Regarding churches, it has been verified that the existence of spaces was essential to separate the sacred space from the rest of the surrounding territory, because the parish churches served as necropolises for a long period of time. Given the initial function assigned to this space, it 
was usually made up of permeable pavements, commonly made of compressed gravel, with walled boundaries.

The analysis of five churches (Fig. 3) shows the existence of this component as the most important of the architectural heritage settings. They are usually associated with the monument's scale, with well-defined limits, assigning a rural character to it, such as the territory demands. The expansion or junctions of these spaces to others create large-scale spaces, as seen in the setting of the monument (Fig. 3 (d)). This maladjustment has contaminated the adjacent spaces, not only in terms of scale but also in terms of excessive use of waterproofing materials, indiscriminately used in successive spaces that were added to the monument, each with a specific function: outside parking, inside parking and access to the cemetery.

An urban logic overlapped the rural logic, with the automobile's accessibility overriding human accessibility. This merging resulted in shattered spaces of the monuments' settings. It is necessary to rethink this, in terms of the materials used and the replacement of the thresholds between the interdependent spaces of the monument.
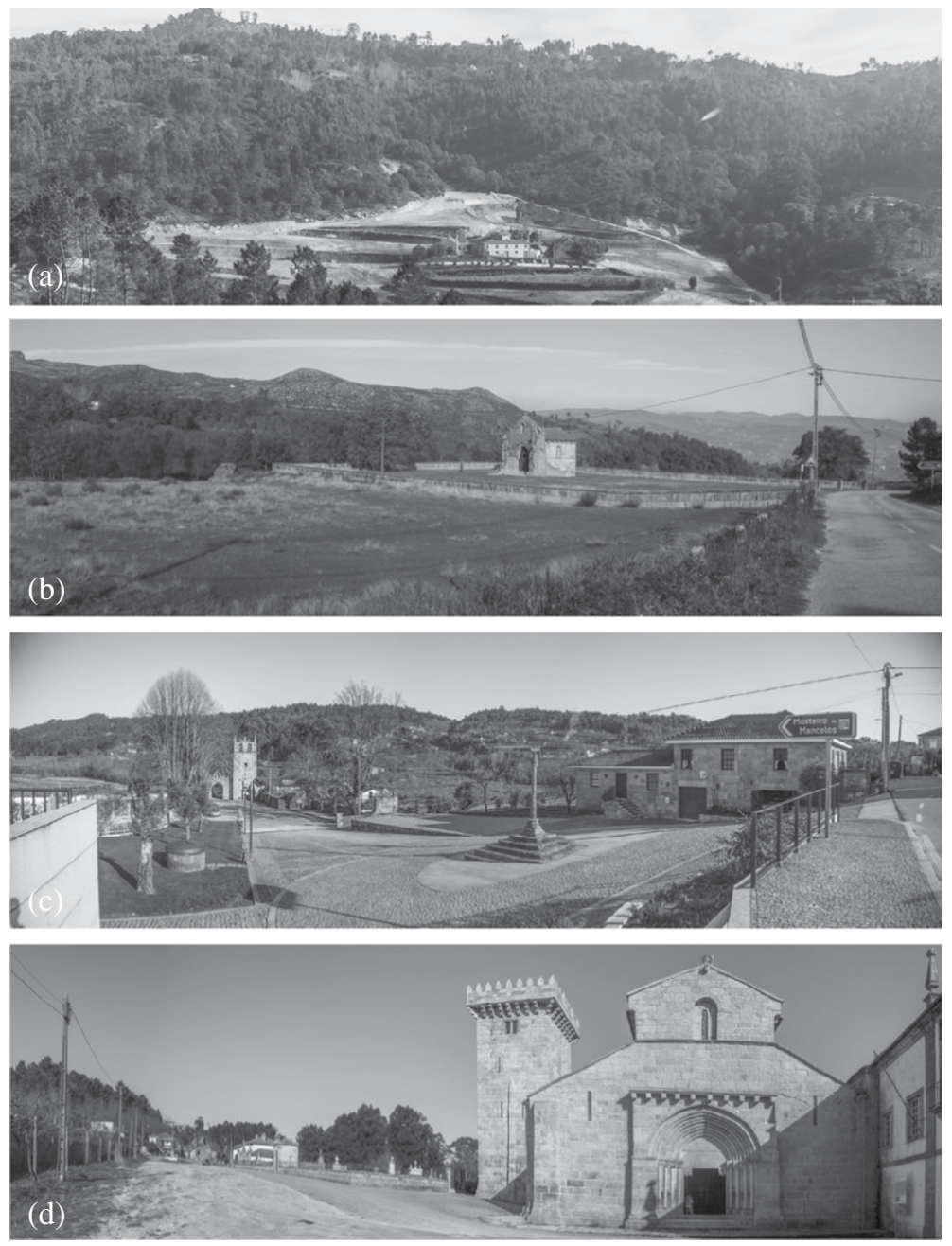

Figure 2: (a) Photographs of the Real Church. (b) Fandinhães Chapel. (c) Mancelos Monastery. (d) Travanca Monastery. 


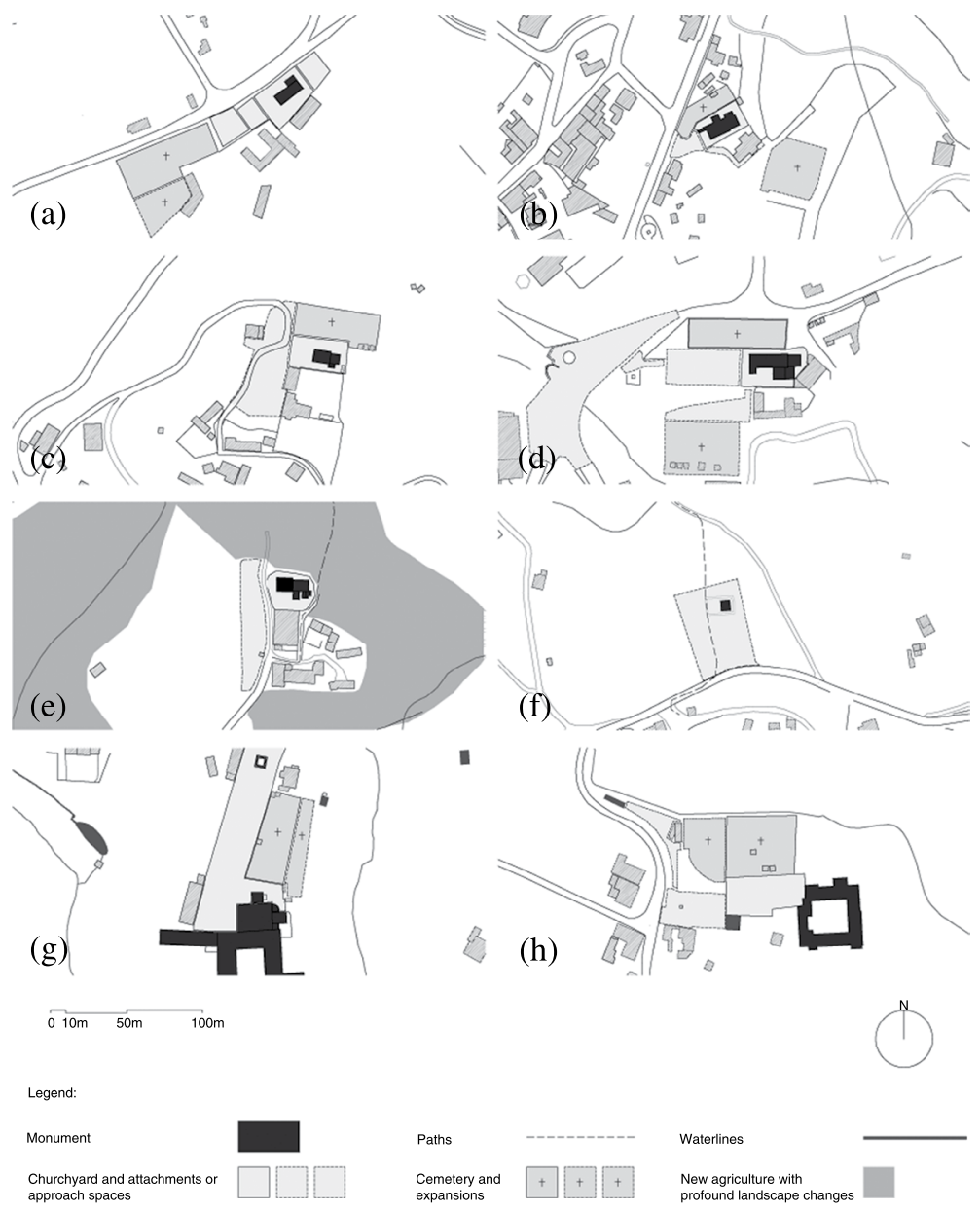

Figure 3: (a) Location plans of Santo Isidoro Church. (b) Tabuado Church. (c) Jazente Church. (d) Vila Boa of Quires Church. (e) Real Church. (f) Fandinhães Chapel. (g) Travanca Monastery. (h) Mancelos Monastery.

In the monuments' settings (Santo Isidoro church (a) and Tabuado church (b)), a clear definition of the boundaries between interdependent church spaces reinforces the integrity and their interdependence with architectural heritage. Existing changes in the periphery, such as the construction of a new cemetery near the monument (b), do not create critical disorders to the interpretation and integration of the monument, due to the strong unity of its spaces. They carry various meanings that reinforce the meaning of place, such as the scale, the transition between constituent spaces and materials, such as the compacted gravel in the church (a), or the double composition of gravel and granite paving stones (b). However, a recent change of pavement in the churchyard (b) challenged its integrity. This occurred with the laying of a false pavement, as shown in Fig. 1(c), where the thickness, grain, colour and texture of the new paving stones do not match the existing traditional sidewalk, creating a 'fake' element, jeopardizing the spiritus loci of that place. 
In the case of the Jazente church's setting, the recent opening of a large space for car parking also challenged the previous modest space to access the monument, as shown in Fig. 1(e). This sudden change in scale and lack of boundary definition between spaces challenged the spiritus loci. This operation will only be mitigated via a careful use of materials in pavements, as well as through space afforestation, reintegrating it into the existing agricultural environment.

Although the Real Church contained well-defined limits of interdependent spaces, the recent change to the surrounding agricultural landscape challenged its integration. The change occurred with the earthmoving of land for planting new vines, knocking down the ancient terraces, paths and vegetation, as shown in Fig. 2(a). This was performed in complete ignorance of the monument's presence, because it was neither classified nor in possession of a ZEP. Guidance regarding this intervention would have prevented the alienation of some fundamental elements for safeguarding the setting of this architectural heritage, such as the vicinal path up the hill, some containment walls, arboreous elements; in addition, earth movements performed in proximity to the church changed the topographic relationship with the slope of the valley. The existence of a study like this would have alerted the local authorities to monitor the project and raise the land owner's awareness in order to carry out the operation with regard for the presence of the heritage asset.

\subsection{Chapel}

Fandinhães Chapel, shown in Fig. 3(f) and Fig. 2(b), contains the definition of a boundary on the mountain space, creating a 'faux' and unreasonable limit to the monument. The scale and materials that constitute the created space, constructed with the purpose of creating a protective space for the monument, misread the setting of this chapel. This is because it has created a space that interrupts the natural topography of the place and the ancestral means of access, which connected the mountain to the village. In the image, other elements that disturb the readability of the chapel and its integration are also visible, like the overhead electric power cables. In this case, the natural topography should be restored with the removal of walls, recreating a perimeter with an appropriate scale for the monument and its scenic environment.

\subsection{Monasteries}

In both monasteries shown in Figs 3(g) and 3(h), there are thresholds that define the approach to the spaces, distinctly demarking the boundaries of those areas. In the case of Travanca Monastery, the space that is closest to the monument, named the yard or terreiro, has its boundaries well defined by the cemetery and enclosure walls, fence and adjacent buildings, creating a space, which is coherent and historically interdependent with the monastery, with suitable pavements. It is a deeply integrated space with the monument, serving as access by defining the clear threshold of the environment that surrounds it. It contains enough symbols to enable the integration and reading of the monument. Although the materials of the floors, walls and some buildings are in a bad state of conservation, its restoration can be easily carried out, providing that it maintains its character and form.

In the case of Mancelos Monastery, the unity that was given to the junction of the two distinct spaces, and through other dependent spaces, created a unique one with different scale, largest and maladjusted to the monument's scale where the different functions, it once had, can no longer be perceived. It refers to the existing yard in front of the monastery, which served as a socializing space away from the access road. The joining of this space with the 
spaces that connect to the access road and the new mortuary eliminated boundaries and culminated in a space, which lacks the scale of the monastery. It is a public space with various textures and no thresholds, more related to the urban road than to the heritage asset and the rural setting in which it is inserted.

\section{CONCLUSION}

The interdependent spaces herein discussed do not serve a function; rather, they reflect the status of the monument and the participating community. Historical architectural forms are not important for defining interventions in the settings of the monuments. As previously mentioned, what becomes important is the understanding of the existence of distinct approach spaces to the monument and, above all, the spaces' boundaries, the thresholds. The spaces defined by these thresholds should capture the spiritus loci of the place formed by the setting and the monument. When defining, delimiting and performing interventions in the settings of the medieval monuments, one should consider the shapes, textures, colours, meanings and uses for enhancing them.

The approach carried out focused on what are considered to be an extremely important factor to be taken into account in the settings of the medieval religious monuments: the thresholds of interdependent spaces of the settings. The continuation of this study could make a contribution to the formalization of intervention criteria and monitoring of the settings of heritage assets, a key aspect for their protection.

\section{ACKNOWLEDGEMENTS}

This work is funded by National Funds through FCT - Foundation for Science and Technology under the project UID/AUR/04026/2013.

\section{REFERENCES}

[1] Malheiro, M. (coord.), Estudo de Valorização e Salvaguarda das Envolventes aos Monumentos da Rota do Românico - $3^{a}$ Fase, Porto, 2015.

[2] Alçada, M., Inventariar, documentar, informar, Urbanidade e Património, ed. Couceiro, J. (coord.), Igaphe: Lisboa, pp. 49-51, 1998.

[3] This inventory refers to information collected from the extinct Portuguese Architectural Heritage Institute (IPPAR, 1992-2007).

[4] This inventory refers to the Inventory of Architectural Heritage (IPA) held by the extinct National Buildings and Monuments Directorate General (DGEMN, 1929-2007), more complete and comprehensive than the former.

[5] Law no. 107/2001, of 8 September.

[6] Marado, C. \& Correia, L. M., The Setting of Architectural Heritage: A research project, In Spatial and Organizational Dynamics, $n^{\circ} 2$, Quarterly Edition, CIEO, Faro, p. 85, 2009.

[7] Art. 43 of Decree- Law no. 309/2009 of 23 October.

[8] AAVV, Património [2000-2006]. Balanço e Perspectivas, IPPAR, Lisboa, p. 82, 2000.

[9] Marado, C. A., Patrimonio conventual y periferia. La salvaguardia de los antiguos espacios conventuales del Algarve. PhD Thesis. Departamento de Urbanística y Ordenación del Territorio, ETSArquitectura, Universidade de Sevilha, pp. 352-353 (vol.1), 2007.

[10] ICOMOS, Xi'an Declaration, On the conservation of the setting of heritage structures, sites and areas, http://www.international.icomos.org/xian2005/xian-declaration-sp. htm., 2005 (Accessed on 15.01.2016). 
[11] ICOMOS, Québec Declaration, On the preservation of the spirit of place, http://www. international.icomos.org/ home.htm., 2008 (Accessed on 15.01.2016).

[12] Ruiz, J.C., El entorno de los bienes inmuebles de interes cultural, Doctorate thesis presented to the Granada University, Department of Art History, Granada, vol. 2, p. 868, p. 648 , p. 649, p. 653, 1993.

[13] Jackson, J.B., Discovering the Vernacular Landscape, Yale University Press: New Haven and London, p. 13, p. 18, 1984.

[14] Almeida, C.A.F., História da Arte em Portugal: o Românico, Editorial Presença: Lisboa, p. 58, p. 59, 2001. 